\title{
Homeopathy and Pluralism of Theories in Medicine Arguments Put Forward to Remove Homeopathic Products from Pharmacies Contradict Actual Scientific Evidence and Suggest Deliberate Misinformation
}

\author{
Peter Friedemann Matthiessen \\ Institute of Integrative Medicine (IfIM), Witten/Herdecke University, Witten, Germany
}

Email address:

Peter.Matthiessen@uni-wh.de

To cite this article:

Peter Friedemann Matthiessen. Homeopathy and Pluralism of Theories in Medicine Arguments Put Forward to Remove Homeopathic Products from Pharmacies Contradict Actual Scientific Evidence and Suggest Deliberate Misinformation. American Journal of Clinical and Experimental Medicine. Vol. 7, No. 2, 2019, pp. 42-46. doi: 10.11648/j.ajcem.20190702.11

Received: January 5, 2019; Accepted: April 13, 2019; Published: June 26, 2019

\begin{abstract}
Founded in 2000 by renowned physicians and researchers on the initiative of Professor Dr. med. Dr. h.c. JörgDietrich Hoppe, then president of the German Medical Association, the Dialogue Forum Pluralism in Medicine (DPM) aims to overcome the traditional partisan bias between conventional medicine and complementary medicine by way of continued critical and objective dialogue between acknowledged representatives of different theoretical and practical approaches, in favour of an Integrative Medicine. The article describes the initiative in Germany as linking up with the concept of Integrative Medicine which originated from the United States and today is spreading across the world. The DPM strives to assess divergent paradigms in medicine for their potential to complement each other. Current DPM members are established proponents of mainstream medicine, anthroposophical medicine, homeopathy, classical naturopathy and Chinese Medicine (TCM). It has become fashionable to belittle homeopathy as being ineffective, using inaccurate statements on the state of research. On behalf of the DPM members as well as numerous medical organisations and renowned physicians and researchers, this article comments on such unjustified claims by means of specific examples. The idea is to establish Integrative Medicine in a spirit of critical but unbiased collaboration between mainstream medicine and selected complementary approaches as a precondition for a fully orchestrated healthcare system that meets the individually varying needs and preferences of the population. In this context, reference is made to a position paper on medical professionalism signed by all DPM members which underlined that conventional and complementary medicine alike are obliged to adhere to scientific standards. Ludwig Fleck and Thomas Kuhn already described tendencies among proponents of specific paradigms to claim privileges for their own paradigm via legislation. However, under Basic Law (German constitution) Article 5 Paragraph 3, the state is generally forbidden to pass judgment on scientific matters in the sense of advocacy of one specific paradigm. It should also be noted that attempts to monopolize a single paradigm favour the emergence of totalitarian thought patterns. In a final vote, the signatories - established medical organisations and numerous physicians and scientists of renown - reject all efforts to pursue totalitarian thought patterns in our healthcare system which are irreconcilable with constitutional law.
\end{abstract}

Keywords: Status of Homeopathy, Therapeutic Efficacy, Placebo Effect, Meta-Analyses, Dispute Between Paradigms, Co-existence of Paradigms, Evidence-Based Integrative Medicine

Against the background of numerous and unsustainable general attacks at national and international level on complementary medicine in general and homeopathy in particular,

this article presents a plea for evidence-based integrative medicine as embodied in German Basic Law, drawn up on behalf of the Dialogue Forum Pluralism in Medicine (DPM) and other institutions and individuals listed below. There are two immediate reasons for this position statement: first, the "Münsteraner Memorandum Homöopathie", presented at the recent $121^{\text {st }}$ meeting of the German Medical Association in Erfurt with the demand to abolish homeopathy as an 
additional medical specialization [1], and second, a pamphlet by Edzard Ernst which appeared in the column "Außenansicht" of Süddeutsche Zeitung on 10 August 2018, where Ernst requests pharmacists to inform customers that homeopathic products are "ineffective placebos", claiming their therapeutic effect is unproven. On 11 October 2018 the column "Meinung" of Süddeutsche Zeitung contained a statement by Werner Bartens which is arbitrary by nature and in conflict with the actual evidence available. Among other things Bartens argues that "anything that bears the label of homeopathy should be removed from pharmacies since no benefit has ever been reliably demonstrated for these and many other such remedies ...", and that "this has been proven a hundred times over".

While a response to the "Münsteraner Memorandum Homöopathie" (authors: Münsteraner Kreis) has already been made [2, 3], the articles by Ernst [4] and Bartens [5] have not been commented upon so far. Ernst suggested to withdraw homeopathic products - which he believes to be placebos without therapeutic effect - from the market by requesting pharmacists to inform customers accordingly. Unfortunately the texts drawn up by E. Ernst and W. Bartens are neither objective nor scientifically substantiated; instead, they present study findings on the therapeutic efficacy of homeopathy in a manner that is tendentious and factually inaccurate. This together with the fact that derogative remarks on homeopathy have become fashionable recently [6-12] has induced the members of the Dialogue Forum Pluralism in Medicine (DPM) as well as the institutions listed below and the physicians and scientists who have signed this reply to draw up a corrective statement with reference to international representative clinical studies, meta-analyses and HTAs on homeopathy [13-25].

Founded in 2000 by Professor Dr. med. Dr. h.c. JörgDietrich Hoppe, then president of the German Medical Association, with the backing of renowned physicians and researchers, the Dialogue Forum Pluralism in Medicine (DPM) aims to overcome the traditional partisan bias between mainstream medicine (conventional medicine) and complementary medicine by way of continued dialogue at eye level between acknowledged proponents of different theoretical and practical approaches. Medical approaches represented within the DPM are mainstream medicine, anthroposophicic medicine, homeopathy, naturopathy and Chinese Medicine (TCM). The DPM strives to separate the wheat from the chaff and establish evidence-based Integrative Medicine as a precondition for a fully orchestrated healthcare system that meets the individually varying needs and preferences of the population. Integrative Medicine does not mean arbitrariness; we, too, believe a distinction between dubious or even unreliable approaches from serious and valuable ones to be essential [26, 28].

The DPM methodically explores different medical approaches for their potential to complement each other, but also for mutual exclusion. Pertinent targets are pursued at the medical facilities listed below. A meticulous but unbiased analysis of the published evidence on the efficacy of homeopathy reveals that high-quality studies substantiate the therapeutic efficacy of homeopathy, and that $90 \%$ of available clinical studies would have to be ignored in order to conclude that homeopathy has no effects [18]. Homeopathy applied by physicians is an important element of an Integrative Medicine which combines the best from conventional medicine and medical homeopathy for the benefit of patients.

After thorough evaluation Switzerland introduced complementary medicine as a constitutional right. As a consequence, homeopathy plus three other complementary approaches are now covered by basic medical insurance in Switzerland and must be taught at tertiary institutions for all health professions. The decision was preceded by a national referendum and a two-fold process of scientific evaluation. Despite assertions to the contrary there are a considerable number of high-quality homeopathy studies, although homeopathy research does not receive institutional backing [18, 23, 30].

Robert Hahn, professor of anaesthesiology and intensive medicine at the Swedish University of Linköping, is the author of more than 300 scientific papers in these two medical disciplines. The winner of several research awards who has never been involved with homeopathic issues before has made the following comment [18]:

"The organization 'Vetenskap och folkbildning' (VoF) (science and public education) launched a summer campaign against homeopathy about three years ago. For the political week in Almedalen the VoF equipped a group of teenagers with t-shirts bearing the inscription 'Jag är skeptisk' (I am sceptical). The group appeared on television together with astronaut Christer Fuglesang, where they had the opportunity to argue against homeopathy for an entire evening, with noone to contradict them. Presenting homeopathy as nothing but a huge bluff, the teenagers all claimed there were no scientific studies to demonstrate that homeopathy actually works.

This disturbing event induced me to write something about available evidence in favour of homeopathy. In the late summer of 2011 my three blogs on the topic attracted considerable attention. My aim was to explore those scientific papers which addressed the question whether homeopathy has a greater statistical effect on medical disorders compared to a placebo (globules or dilutions). [...]

In 2000 Ernst wrote a so-called meta-analysis on homeopathy which actually was nothing but a systematic overview. [...] So who can be trusted? We may start by weeding out Edzard Ernst. I have read some of the studies he has published, and all of them are dubious."

As to the Australian study quoted by Edzard Ernst as proof of the inefficacy of homeopathy, it must be noted that this is not a meta-analysis but a literature research which a priori excluded homeopathy studies with less than 150 participants; as a consequence, a considerable share of datasets were not included in the evaluation $[30,31]$. This means that the study quoted by Ernst has no validity. Accordingly, the study was not published in a peer reviewed journal. 
Accused of having falsified the review on homeopathy [31], the National Health \& Medical Research Council (NHMRC) as the highest public health authority in Australia had to admit to the Australian Senate that they manipulated the report. Only five out of originally 176 studies made it to the final round of high-quality studies. The decision not to include other studies in the analysis was obviously based on the fact that many of these studies showed positive findings [31].

A position paper on medical professionalism and complementary medicine published in Deutsches Ärzteblatt in 2010 and signed by all DPM members underlined that conventional and complementary medicine alike are obliged to adhere to scientific standards [32].

Ernst is also inaccurate in equating placebo effect with therapeutic ineffectiveness. Winfried Rief corrected this claim in a commendable and highly competent reply which appeared in Süddeutsche Zeitung (column "Außenansicht") on 22 August 2018. Rief refers to findings from modern placebo research to point out that placebo interventions may be highly effective and sustainable and that they depend on patients' and physicians' positive (or negative) expectations, so that not the pill in itself is important but what it stimulates in the patient. Rief urgently recommends more intensive research into placebo effects, also in view of their role in mainstream medicine, and the integration of "placebo-related interventions like homeopathy, acupuncture and some naturopathic approaches" into medical and pharmaceutical science.

For some decades the idea has been taking hold worldwide that a fully orchestrated health system must be based on Integrative Medicine in order to meet the manifold and individually varying needs and preferences of the population, and thereby the requirements of evidence-based medicine as proclaimed by Sackett [33]. The concept of Integrative Medicine describes a substantiated and transparent coexistence of paradigms in the sense of different theoretical and practical approaches.

The US-American Academic Consortium for Integrative Medicine and Health with a membership of more than 60 leading medical schools defines Integrative Medicine as follows: "Integrative medicine and health reaffirms the importance of the relationship between practitioner and patient, focuses on the whole person, is informed by evidence, and makes use of all appropriate therapeutic and lifestyle approaches, healthcare professionals and disciplines to achieve optimal health and healing." [34]. To those involved, the concept of Integrative Medicine is a mission statement which overcomes partiality between different schools of thought in favour of integration, associated with an objective search for therapy approaches best suited to the individual patient. By the end of 2015, approximately 121,000 resident doctors in Germany distributed over ca. 95,000 surgeries applied complementary interventions. This means that every second physician has already integrated complementary medicine into daily medical practice.

Conclusion
All those who with eschatological doggedness demand the exclusion of complementary therapies from reimbursement via public health funds, and a ban on homeopathy and withdrawal of homeopathic products, confirm what Thomas Kuhn [35, 36] and Ludwig Fleck [37] described as the dynamics of claiming privileges for one's own paradigm via legislation. But Germany is a secular country, and under Basic Law (German constitution) Article 5 Paragraph 3, the state is generally forbidden to pass judgment on scientific matters in the sense of advocacy of one specific paradigm. Maunz et al. address this aspect in detail in their commentary to constitutional law: persons active in research and teaching are authorized to reject any state intervention to influence the process of gaining and conveying scientific findings - subject to the obligation of loyalty according to Basic Law Article 5 Paragraph 3. Science, so Maunz et al., offers a sphere of personal and autonomous responsibility for each researcher, free from state control [38]. The state is forbidden by Basic Law to give preferential treatment to individual scientific approaches or medical paradigms. Accordingly, a parliamentary committee charged with revising pharmaceutical law in connection with the new Medical Products Act passed in 1976 declared that "in a controversial debate of scientific positions the legislator's task cannot be to unilaterally establish specific methods and thus determine a generally binding 'state of scientific knowledge'; instead, it must be ensured that the scientific pluralism of drug therapies is reflected in the approval of drugs or procedures" [39].

Homeopathic products are handled by a separate committee at the Federal Institute for Drugs and Medical Devices (AfArM), are described in the German Pharmacopoeia of Homeopathy (HAB), and incorporated in the German Social Security Code (SGB V).

When Hans-Georg Gadamer, doyen of hermeneutic philosophy in Germany, was interviewed at the age of 100 by the SPIEGEL magazine on 21 February 2000, and asked to sum up the essence of his philosophy in one sentence, his answer was: "The opponent might be right."

You do not conduct a conversation if there is no chance that your interlocutor is right. We in the Dialogue Forum have modified the sentence as follows: "The opponent might be right as well" [27].

Monoparadigmatic reductionism will always result in totalitarian ideology, whether intended or not, with no respect for citizens' rights of self-determination, no tolerance towards proponents of different theoretical and practical approaches, no recognition of individual quest for knowledge, nor respect for human dignity. Is that really what we want for our system of medicine and healthcare: totalitarian structures?

We as members of the Dialogue Forum Pluralism in Medicine (DPM) and all other signatories will persist in our efforts to maintain and develop scientific and ethical pluralism in medicine as the fundament of a liberal and democratic health system - a system that permits health care in personal responsibility, consideration of the public interest and critical benefit evaluation, with a focus on citizens' and 
patients' individually varying needs and preferences. Therefore we firmly reject any totalitarian thought patterns and power claims like those behind the "Münsteraner Memorandum Homöopathie" and the texts published by Edzard Ernst and Werner Bartens in Süddeutsche Zeitung on 18 August 2018 and 11 October 2018 as irreconcilable with constitutional law. Information to the general public on the therapeutic efficacy of homeopathy should not be based on pre-conceived and biased notions but on intellectual honesty.

\section{Signatories}

Dialogforum Pluralismus in der Medizin (DPM) Dialogue Forum Pluralism in Medicine

Hufelandgesellschaft e.V. Ärztlicher Dachverband für Naturheilkunde und Integrative Medizin - Hufeland Society

- Physicians Umbrella Organization of Naturapathy, Complementary and Integrative Medicine Association in Germany

Wissenschaftliche Gesellschaft für Homöopathie (WissHom) - Scientific Society for Homeopathy

Deutscher Zentralverein homöopathischer Ärzte (DZVhÄ)

- German Central Association of Homepathic Physicians

Gesellschaft anthroposophischer Ärzte in Deutschland e.V. (GAÄD) - Physicians` Association for Anthroposophic Medinice in Germany

Deutsche Ärztegesellschaft für Akupunktur (DÄGfA) German Medical Society for Acupuncture

Gesundheit Aktiv - Health Active - Citizen and Patient Association

Privatärztlicher Bundesverband e.V. für Privatärzte in Deutschland (PBV) - German Doctors Association of Private Medicine

\section{Address for Correspondence}

Prof. Dr. med. Peter Friedemann Matthiessen

$1^{\text {st }}$ spokesman of the Dialogue Forum Pluralism in Medicine (DPM)

Head of Division "Plurality in Medical Approaches", Institute of Integrative Medicine (IfIM) at Witten/Herdecke University

Gerhard-Kienle-Weg 4

D-58313 Herdecke

Email: peter.matthiessen@uni-wh.de

\section{References}

[1] Münsteraner Memorandum Homöopathie. Ein Statement der Interdisziplinären Expertengruppe „Münsteraner Kreis” zur Abschaffung der Zusatzbezeichnung Homöopathie. Korrespondenzadresse: Dr. Christian Weymayr, c/o Lehrstuhl für Medizinethik, Institut für Ethik, Geschichte und Theorie der Medizin, Universität Münster, Von Esmarch-Str. 62, D48149 Münster, christian.weymayr@web.de.

[2] Dialogforum Pluralismus in der Medizin (DPM): Zusatzbezeichnung Homöopathie stärkt Evidenzbasierte
Integrative Medizin, Autor: Matthiessen, Peter F. Einsehbar unter: http://www.dialogforumpluralismusindermedizin.de/dpm_dll?pageID $=166$

[3] Matthiessen Peter F. (2018) „Der Andere könnte auch Recht haben“. Monitor Versorgungsforschung 2018; 3: 42-44.

[4] Ernst Edzard. (2018) Homöopathie raus aus den Apotheken. In: Süddeutsche Zeitung, Außenansicht, 10.08.2018.

[5] Bartens Werner. (2018). Apotheken. Erste Hilfe. In: Süddeutsche Zeitung. Wissen. 11.10.2018.

[6] Ernst Edzard, Pittler MH. (2000). Re-analysis of previous meta-analysis of clinical trials of homeopathy. J Clin Epidemiol 2000; 53: 1188.

[7] Ernst Edzard. (2002). A systematic review of systematic reviews of homeopathy. Br J Clin Pharmacol 2002; 54: 57782.

[8] Shang Aijing, Huwiler-Müntener Karin, Nartey Linda, Jüni Peter, Dörig Stephan, Sterne Jonathan A. et al. (2005). Are the clinical effects of homoeopathy placebo effects? Comparative study of placebo- controlled trials of homoeopathy and allopathy. Lancet; 366: 726-732.

[9] Shaw David Martin. (2012). The Swiss Report on homeopathy: a case study of research misconduct. Swiss Med Wkly; 142: w13594.

[10] Schmacke Norbert. (Hrsg.) (2015). Der Glaube an die Globuli - Die Verheißungen der Homöopathie. Suhrkamp, Berlin.

[11] Schmacke Norbert. (2016). Homöopathie: Der Globuspokus geht weiter. Doc-Check News: 1-4.

[12] Linde Klaus, Clausius Nicola, Ramirez Gilbert, Melchart Dieter, Eitel Florian, Hedges Larry V et al. (1997). Are the clinical effects of homeopathy placebo effects? A meta-analysis of placebocontrolled trials. Lancet 1997;350:834-843.

[13] Linde Klaus, Clausius Nicola, Ramirez Gilbert, Melchart Dieter, Eitel Florian, Hedges Larry V et al. (1998). Overviews and metaanalysis of controlled clinical trials of homeopathy. In: Ernst E, Hahn EG (eds.). Homeopathy. A critical appraisal. ButterworthHeinemann, Oxford. S. 101-106.

[14] Kleijnen Jos, Knipschild Paul, terRied Gerren. (1991). Clinical trials of homeopathy. BMJ 302: 316323.

[15] Mathie Robert T, Lloyd Suzanne M, Legg Lynn A, Clausen Jürgen, Moss Sian, Davidson Jonathan R et al. Randomised placebo-controlled trials of individualised homeopathic treatment: Systematic review and meta-analysis.Syst Rev. 2014 Dec 6; 3:142. doi: 10.1186/2046-4053-3-142.

[16] Cucherat Michael, Haugh Margaret C., Gooch Michael, Boissel Jean-Pierre. (2000). Evidence of clinical efficacy of homeopathy. (A meta-analysis of clinical trials.) Eur J Clin Pharmacol 2000;56:27-33.

[17] Bornhöft Gudrun, Matthiessen Peter F. (eds). (2011) Homeopathy in Health Care - Effectiveness, Appropiateness, Safety, Costs. An HTA Report on Homeopathy as part of the Swiss Complementary Medicine Evaluation Programme. Springer-Verlag, Berlin/Heidelberg.

[18] Hahn Robert G. (2013) Homeopathy: meta-analyses of pooled clinical data. ForschKomplementmed. 2013; 20 (5): 376-81. doi: $10.1159 / 000355916$. 
[19] Der aktuelle Stand der Forschung zur Homöopathie“. (2016) Forschungsreader der Wissenschaftlichen Gesellschaft für Homöopathie. WissHom. einsehbar unter: https://www.homoeopathie-online.info/category/wisshom/.

[20] Gleiss Andreas, Frass Michael, Gaertner Katharina. (2016) Re-analysis of survival data of cancer patients utilizing additive homeopathy. Complement Ther Med Aug; 27:65-7. doi: 10.1016/j.ctim.2016.06.001. Epub 2016 Jun 7.

[21] Frass Michael, Dielacher Christoph, Linkesch Manfred, Endler Christian, Muchitsch Ilse, Schuster Ernst et al. (2005a) Influence of potassium dichromate on tracheal secretions in critically ill patients. Chest 2005a; 127: 936-41.

[22] Ammon Klaus v, Bornhöft, Gudrun, Maxion-Bergemann Steffi, Righetti Marco, Baumgartner Stephan, Thurneysen André et al. (2013). Familiarity, objectivity - and misconduct. Counterstatement to Shaw MD. The Swiss Report on homeopathy: a case study of research misconduct. Swiss Med Wkly. 2013; 143: w13720.

[23] Frass Michael, Linkesch Manfred, Banyai Susanne, Resch Gerhard, Dielacher Christoph, Lobl Thomas et al. (2005b). Adjunctive homeopathic treatment in patients with severe sepsis: a randomized, double-blind, placebo-controlled trial in an intensive care unit. Homeopathy 2005b; 94: 75-80.

[24] Teut Michael, Lucae Christian, Wischner Matthias, Dahler Jörn D. (2015). Der Glaube an die Globuli" - eine kritische Rezension. www.informationen-zur-homoeopathie.de. Posted on 2. August 2015 in Gesellschaft für Homöopathie.

[25] Willich Stefan N, Girke Matthias G, Hoppe Jörg-Dietrich, Kiene Helmut, Klitzsch Wolfgang, Matthiessen Peter F. et al. (2004) Schulmedizin und Komplementärmedizin. Verständnis und Zusammenarbeit müssen vertieft werden. Deutsches Ärzteblatt; 110, 19:A-1314-1319, B-1087-1091, C-10511055, Köln.

[26] Matthiessen Peter F. (2011a) Paradigmenpluralität und Individualmedizin. In: Peter F. Matthiessen (Hrsg.). Patientenorientierung und Professionalität. Festschrift 10 Jahre Dialogforum Pluralismus in der Medizin. Verlag Akademische Schriften (VAS): Bad Nauheim, 2. erweiterte Auflage.

[27] Matthiessen Peter F. (2011b). 10 Jahre Dialogforum Pluralismus in der Medizin. Warum es uns gibt, wer wir sind und was wir wollen, in: Peter F. Matthiessen (Hrsg.). Patientenorientierung und Professionalität. Festschrift 10 Jahre Dialogforum Pluralismus in der Medizin. 2. erweiterte Auflage. Bad Homburg. Verlag Akademische Schriften (VAS).
[28] Matthiessen Peter F. (2011c, 2013) Einzelfallforschung zwischen Evidence based Medicine and Narrative based Medicine. ICE 11. Köthen (Anhalt) www.wisshom.de.

[29] Dachverband Komplementärmedizin, Schweiz. Komplementärmedizin ist Pflichtleistung der Krankenversicherung in der Schweiz. Medienmitteilung vom 16. Juni 2017.

[30] www.gesundheit-aktiv.de/aktuelles/Nachrichten/882-die-kruxmit-der-evidenz.html

[31] www.yourhealthyourchoice.com.au/news-features/sciencefact-or-fiction-nhmrcadmits-they-did-not-use-acceptedscientific-methods-2/

[32] Kiene Helmut, Heimpel Hermann, gemeinsam verfasst von den Mitgliedern des Dialogforum Pluralismus in der Medizin. (2010) Ärztliche Professionalität und Komplementärmedizin. Was ist seriöses therapieren? Medizinpluralismus und die Verpflichtung zu Wissenschaftlichkeit erscheinen nur auf den ersten Blick als ein Widerspruch. Deutsches Ärzteblatt Jg.107. Heft 12. 26. März 2010.

[33] Sackett David, Richardson W. Scott, Haynes R. Brian. (1997) Evidence Based Medicine: How to practice and teach EBM. Churchill Livingstone, New York, Edinburgh, London.

[34] The Academic Consortium for Integrative Medicine and Health. (2004, revised May 2015) Accessible unter https://www.imconsortium.org/about/about-us.cfm; accessed Mai 22, 2017.

[35] Kuhn Thomas S. The Structure of Scientific Revolutions. Chicago. 1962.

[36] Kuhn Thomas S. Die Entstehung des Neuen. Suhrkamp. Frankfurt a. Main. 1977.

[37] Fleck Ludwig. (1993) Die Entstehung und Entwicklung einer wissenschaftlichen Tatsache. Einführung in die Lehre vom Denkstil und Denkkollektiv. Suhrkamp. (Der Text ist identisch mit der Erstausgabe bei Benno Schwabe und Co. von 1935).

[38] Maunz Theodor, Dürig Günter, Herzog Roman, Scholz Rupert. (1980) Grundgesetz Kommentar. C.H. Beck'sche Verlagsbuchhandlung. München.

[39] Deutscher Bundestag, Ausschuss für Jugend, Familie und Gesundheit. (1976) Bericht zur Neuordnung des Arzneimittelrechts. Drucksache 7/5091 vom 28.04.1 